\title{
A New Method of Compost Preparation from Vegetable Waste and Dried Leaf Litters
}

\author{
A. G. Girish*, P. Sakthivel and Alice R.P. Sujeetha
}

National Institute of Plant Health Management, Ministry of Agriculture and Farmers Welfare, Govt. of India, Rajendranagar, Hyderabad - 500030, India

*Corresponding author

\section{A B S T R A C T}

\begin{tabular}{l}
\hline K e y w o r d s \\
Vegetable waste, \\
$\begin{array}{l}\text { Dried leaf litters, } \\
\text { Compost, } \\
\text { Bioinoculum }\end{array}$ \\
\hline Article Info \\
\hline $\begin{array}{l}\text { Accepted: } \\
10 \text { July } 2020 \\
\text { Available Online: } \\
\text { 10 August } 2020\end{array}$ \\
\hline
\end{tabular}

Compost is decayed organic material which can be used as a fertilizer for growing plants. There are severalconventional methods of compost preparation are being practiced across the country. NIPHM used the barrel composting and deep bed composting methods. For barrel composting the vegetable waste were collected from NIPHM hostel and residential staff quarters regularly. In deep bed composting method, the litters collected at quarters at regular intervals were used. To accelerate the process of decomposition bioinoculum developed by NIPHM was used. Bioinoculum and compost prepared were subjected to physicochemical and nutritional analysis. On physicochemical analysis the bioinoculum were identified as Pseudomona ssp and Bacillus sp.In NIPHM bio-inoculum method Pseudomonas sp were used as decomposer for composting called NIPHM bioinoculum method. Compost prepared by new methods undergone for physicochemical analysis i.e. moisture content, $\mathrm{pH}$, electrical conductivity, and organic carbon was found as good as in control (A regular method country wide). In nutritional analysis Potassium, Phosphorous other micronutrients were found to be more than required in both the composts prepared by NIPHM and also in control. The development of composting took place in 40-50 days for barrel composting, whereas 60-70 days for conventional method. In deep bed composting, the entire process of natural composting took 90 to 120 days, whereas NIPHM modified technique took90 days. Total $595 \mathrm{~kg}$ vegetable wastes were collected and $160 \mathrm{~kg}$ compost was harvested from all the three methods. The harvested compost was used in plot in which Spinach (Spinacia oleracea) was grown. The spinach growth in vegetable compost was compared with FYM, Earthworm compost and control (without compost). The growth of the spinach was superior in producing more root length and shoot length in vegetable compost.

\section{Introduction}

In India it is estimated that nearly 70 million ton organic waste is generated annually which is either burned or land filled (Bhiday, 1994).
Use of microbial inoculum to convert vegetable waste into compost is a feasible and potential technology. It is a simple biotechnological process of composting, in which certain species of bacteria are used to 
enhance the process of waste conversion and produce a better end product. Many fruits and vegetables present nearly ideal conditions for the survival and growth of many types of microorganisms. In the present study, a simple microbiological process, this could provide a solution to the problem of vegetable kitchen waste disposal for recycling of solid waste into useful compost by the action of decomposing bacteria was carried out.

\section{Material and Methods}

\section{Quantity of waste generation and collection at NIPHM:}

About 30 to $40 \mathrm{~kg}$ of wastes are regularly generated in every month at NIPHM canteen, and NIPHM residential premises. Every house was provided with two dust bins for segregation of dry and wet wastes. The wastes are collected and cut in to small pieces and transferred to plastic barrel for decomposition. Total vegetable waste collected were dried uniformly, For the collection of other wastes viz., plastic, paper, hazardous, dry, NIPHM have arranged the different bins for segregation of different wastes like plastic, paper, hazardous, dry etc. which are collected by GHMC every week. Following two treatment methods of waste management practices was developed at NIPHM.

\section{Development of bio inoculum at NIPHM}

To collect bioagents from the waste vegetables soil samples along with vegetable waste were collected from area where the market vegetables dumped. The soils and vegetable waste mixed samples were collected in sterile polythene zip lock covers and stored in the refrigerator without losing moisture content. Then the soil samples along with waste were rinsed thoroughly with distilled water and serially diluted up to $10^{-7}$.
The highest dilutions were taken for analyzing the total microbial count by using Nutrient agar medium at $33-35^{\circ} \mathrm{C}$ for 24 hours.

\section{Barrel composting by NIPHM method}

Daily wet/vegetable waste from the NIPHM residents and NIPHM canteen were collected and then cut into small pieces and transferred to plastic barrel (100 lit capacities) on regular basis. Before pouring in to drums the vegetable pieces were mixed with coco peat, sanitizer and bio inoculum added to accelerate the compositing process. Then regular mixing carried out periodically to accelerate the decomposition of wastes. The flow chart for preparation is provided in Fig.1.

\section{Barrel composting by Regular method}

The experiments were conducted in plastic drums of 100 lit capacities as described above. Routine method of vegetable composting was used as control treatment as check. The flow chart for preparation is provided in Fig.2. Daily 5 kilogram of the vegetable wastes were transferred into plastic barrel. NIPHM bio-inoculum $10 \mathrm{ml}$ of Pseudomonas sp (pure culture) added into the wastes. In regular method the bio-inoculum was not added. Both experimental setups were periodically mixed well. Excess water will get rid of through the holes provided at the bottom of barrel. After 60-70 days compost was harvested. The composts prepared by NIPHM and Regular method were subjected to microbial and physio chemical analysis.

\section{Dry leaf litters wastes composting by using NIPHM bio-inoculum}

Dry leaf litters at NIPHM quarters was collected every week. This litter was converted into the compost by using the NIPHM bioinoculum. Pit method was used 
for the composting and flow chart of compost preparation is provided below. The collected composts were subjected to microbial and physio chemical analysis.

\section{Physiochemical analysis}

Moisture Content, $\mathrm{pH}$ and organic carbon were determined at $0,10,20,30,40,50,60$ and 70 days during preparation of composting. $\mathrm{pH}$ was determined by method described by ISI Bulletin (1982). The organic carbon was determined by the empirical method followed by Walkely and Black (1934). Moisture \% was calculated (Thiruppathiet.al; 2005) for each of the compost by

a) Weighing a small container

b) Weighing $10 \mathrm{~g}$ of the material into the container

c) Drying the sample for 24 hours in a 105 110 degree $C$ oven

d) Re-weight the sample, subtract the weight of the container, and determine the moisture content using the following equation:

$\mathrm{M}_{\mathrm{n}}=\left(\left(\mathrm{W}_{\mathrm{w}}-\mathrm{W}_{\mathrm{d}}\right) / \mathrm{W}_{\mathrm{w}}\right) \quad \mathrm{x}$ 100in which: $\mathrm{M}_{\mathrm{n}}=$ moisture content $(\%)$ of material $\mathrm{n}$ $\mathrm{W}_{\mathrm{W}}=$ wet weight of the sample, and $\mathrm{W}_{\mathrm{d}}=$ weight of the sample after drying.

The final compost products were again tested for the $\mathrm{pH}$, electrical conductivity organic carbon, Calcium, Potassium, Phosphorus and Micronutrients with a help of Soil testing laboratory, Rajendranagar, Government of Telangana.

\section{Results and Discussion}

\section{Development of Bioinoculum}

According to Bergey's Manual of Determinative Bacteriology, the microorganisms were isolated by using King
A and Kings B medium. Morphological and culture characteristics such as abundance of growth, pigmentation, optical characteristics, form, size, margin and elevation of the microbes were studied on Nutrient agar plates. The highest dilutions were taken for analyzing the total microbial count by using Nutrient agar medium at $33-35^{\circ} \mathrm{C}$ for 24 hours. Standard Plate Count (SPC) was carried out by spread plate Technique. Fig 5.Identification of Bacteria Gram's staining technique was carried out to identify gram positive and gram negative bacteria. Depending upon the morphological and biochemical characters isolates were identified as Bacillus species and Pseudomonas species (Table 1).

\section{Physical and chemical analysis of Bioinoculum}

Twenty four hr old culture was used for the physicochemical analysis. In physical analysis it was noticed that both culture bacterial cells are rod shaped. Under the biochemical analysis 12 tests were conducted. Based on the biochemical analysis, the isolates were identified as Bacillus sp. and Pseudomonas sp. Details of Physicochemical analysis are shown in Table. 2

\section{Physiochemical Analysis of the compost}

The $\mathrm{pH}$ of the compost was lower in all the treatments than their initial values (Table 2). The decrease in $\mathrm{pH}$ value at the final stage of compost formation may be due to the production of $\mathrm{CO}_{2}$ and organic acids by microbial metabolism during decomposition of different substrates in the vegetable waste (Albanell et al., 1998). Decrease in $\mathrm{pH}$ may be an important factor in Nitrogen retention as this element is lost as volatile ammonia at highest $\mathrm{pH}$ (Gautham et al., 2010). According to Viel et al., (1987) loss in organic carbon might be responsible for nitrogen 
enhancement. Pseudomonas bacteria also have great impact on nitrogen transformation in manure, by enhancing nitrogen mineralization, so that mineral nitrogen may be retained in the nitrate form (Atiyeh et al., 2000b). Nitrogen was found high in vegetable waste compost and leaf litter compost compared to control. All other micro and micro nutrients are medium to high except $\mathrm{Fe}$ and $\mathrm{Mn}$. In the present study, the vegetable and leaf litter wastes were effectively decomposed by the microbes. It is due to the increased microbial activity in the compost. Daywise details of the moisture content, $\mathrm{pH}$ and Organic carbon content day wise is provided in Table 2. Biochemical analysis was carried out for the final product also and details are provided in Table 3.

Flow chart of Compost procedure from the leaf litters

Make a pit of 2'deep X 3'width X 8' length

Spread dry grass at bottom

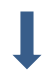

Spread litters in layers on it

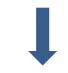

After every two layers add 1-2 kg neem leaves (dry/fresh)

Spray NIPHM Decomposer 10-15 ml by mixing in $1000 \mathrm{ml}$ water in each layer and wet the leaves

Continue the process till pit is full

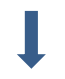

Collect the litters in polythene cover and closed it.

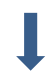

After 12 days remove the polythene cover and do mixing and again cover with polythene (Check for moisture at the time of every mixing)

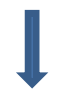

Continue process every month till 60 days

Observed for decomposition state if required continue for another one month 
Table.1 Morphological \& biochemical profile of the bacterial isolates

\begin{tabular}{|c|c|c|c|}
\hline S.No & Characteristic/ Test & $\begin{array}{l}\text { Isolate } 1 \\
\text { (Bacillus } \\
\text { Species) }\end{array}$ & $\begin{array}{c}\text { Isolate } 2 \\
\text { (Pseudomonas } \\
\text { Species) }\end{array}$ \\
\hline 1. & Shape & Rod & Rod \\
\hline 2. & Gram's staining & + & - \\
\hline 3. & Motility & + & - \\
\hline 4. & Endospore & + & - \\
\hline 5. & Indole test & - & - \\
\hline 6. & Methyl red test & - & - \\
\hline 8. & Gelatin hydrolysis & + & - \\
\hline 9. & Carbohydrate utilization & + & + \\
\hline 10. & Catalase test & + & + \\
\hline 11. & Oxidase test & + & + \\
\hline 12. & Nitrate reduction test & + & + \\
\hline 13. & Starch hydrolysis test & + & - \\
\hline
\end{tabular}

Table.2 Physiochemical analysis of the compost prepared

\begin{tabular}{|c|c|c|c|c|c|c|c|c|c|}
\hline \multirow[t]{2}{*}{ Days } & \multicolumn{3}{|c|}{ Moisture content $(\%)$} & \multicolumn{3}{|c|}{$\mathbf{P}^{\mathbf{H} \text { values }}$} & \multicolumn{3}{|c|}{$\begin{array}{c}\text { Organic carbon content } \\
(\%)\end{array}$} \\
\hline & $\begin{array}{l}\text { Regular } \\
\text { Method } \\
\text { (Control) }\end{array}$ & $\begin{array}{c}\text { NIPHM } \\
\text { Vegetable } \\
\text { waste }\end{array}$ & $\begin{array}{c}\text { NIPHM } \\
\text { leaf litter } \\
\text { waste }\end{array}$ & $\begin{array}{l}\text { Regular } \\
\text { Method } \\
\text { (Control) }\end{array}$ & $\begin{array}{c}\text { NIPHM } \\
\text { leaf litter } \\
\text { waste }\end{array}$ & $\begin{array}{c}\text { NIPHM } \\
\text { Vegetable } \\
\text { waste }\end{array}$ & $\begin{array}{l}\text { Regular } \\
\text { Method } \\
\text { (Control) }\end{array}$ & $\begin{array}{c}\text { NIPHM } \\
\text { Vegetable } \\
\text { waste }\end{array}$ & $\begin{array}{l}\text { NIPHM } \\
\text { leaf } \\
\text { litter } \\
\text { waste }\end{array}$ \\
\hline $\mathbf{0}$ & 58 & 58 & 58 & 6.5 & 6.5 & 6.5 & 20 & 22.00 & 20.00 \\
\hline 10 & 56 & 59 & 57 & 6.6 & 6.6 & 6.7 & 19 & 22.00 & 20.00 \\
\hline 20 & 50 & 50 & 45 & 6.8 & 6.7 & 6.8 & 18.5 & 20.00 & 19.50 \\
\hline 30 & 46 & 47 & 39 & 6.7 & 6.8 & 7.0 & 17.32 & 19.50 & 19.00 \\
\hline 40 & 41 & 45 & 34 & 6.9 & 7.4 & 7.8 & 18.00 & 19.00 & 18.00 \\
\hline 50 & 39 & 38 & 31 & 7.2 & 7.6 & 8.0 & 17.00 & 18.00 & 17.50 \\
\hline 60 & 38 & 38 & 31 & 8.0 & 7.6 & 8.2 & 16.00 & 17.5 & 16.00 \\
\hline 70 & 36 & 37 & 30 & 8,0 & 7.8 & 8.5 & 16.50 & 15.5 & 14.5 \\
\hline
\end{tabular}


Table.3 Chemical properties of final compost product

\begin{tabular}{|c|c|c|c|}
\hline Chemical Properties & $\begin{array}{l}\text { NIPHM leaf litter } \\
\text { waste compost }\end{array}$ & $\begin{array}{l}\text { NIPHM Vegetable } \\
\text { waste compost }\end{array}$ & $\begin{array}{l}\text { Regular } \text { Method } \\
\text { (Control) }\end{array}$ \\
\hline Electrical Conductivity & 0.11 (Normal) & 0.12 (Normal) & 0.19 (Normal) \\
\hline pH & $\begin{array}{l}8.26 \text { (Medium } \\
\text { alkaline) }\end{array}$ & $\begin{array}{l}8.36 \text { (Medium } \\
\text { alkaline) }\end{array}$ & $\begin{array}{l}8.2 \text { (Medium } \\
\text { alkaline) }\end{array}$ \\
\hline Organic Carbon & Low & Low & Low \\
\hline Available Phosphorous & 14 (Medium) & 11(Medium) & 16(Medium) \\
\hline Available Potassium & 148 (High) & 107 (Medium) & 184(High) \\
\hline $\mathbf{Z n}$ & 1.139 (High) & 0.530 (Low) & 0.830 (High) \\
\hline Mn & 0.322 (Low) & 0.268 (Low) & 0.540 (Low) \\
\hline Fe & 1.632(Low) & 1.404(Low) & $1.216(\mathrm{Low})$ \\
\hline $\mathbf{C u}$ & 0.365 (High) & 0.188 (Low) & 0.446 (High) \\
\hline
\end{tabular}

Fig.1 Composting by using NIPHM bio-inoculum

\begin{tabular}{|l|l|l|l|l|l|l|}
\hline & $\begin{array}{l}\text { Kitchen } \\
\text { waste cut in } \\
\text { to bits }\end{array}$ & $\begin{array}{l}\text { Sun drying } \\
\text { for 2-3 days }\end{array}$ & $\begin{array}{l}\text { Mixing } \\
\text { NIPHM with } \\
\text { bioinoculum and } \\
\text { poured in drums }\end{array}$ & $\begin{array}{l}\text { Compost under } \\
\text { preparation } \\
\text { after 20 days }\end{array}$ & $\begin{array}{l}\text { End product } \\
\text { after 40 days } \\
\text { (Compost) }\end{array}$ & $\begin{array}{l}\text { After ground } \\
\text { compost after } \\
50 \text {-60 days }\end{array}$ \\
\hline
\end{tabular}

Fig.2 Composting by regular method

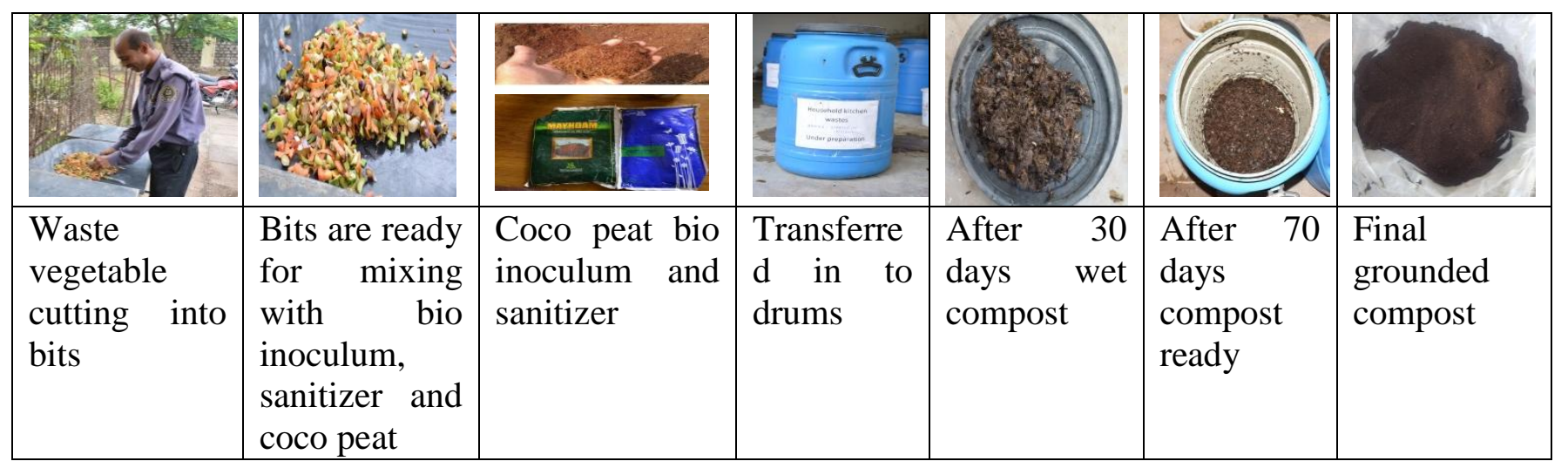


Fig.3 Litters after mixing with bio-inoculum covered with polythene sheet

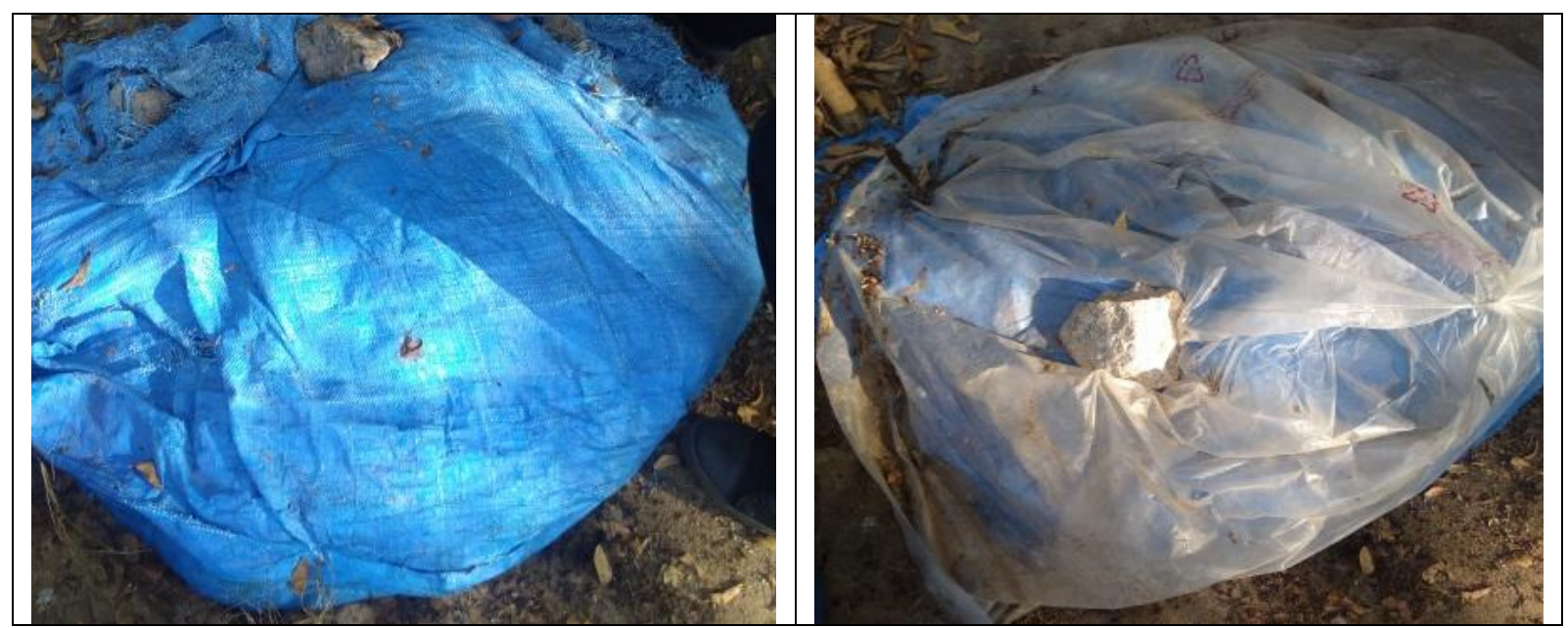

Fig.4 a. Mixing after 12 days

b. Compost after 60 days

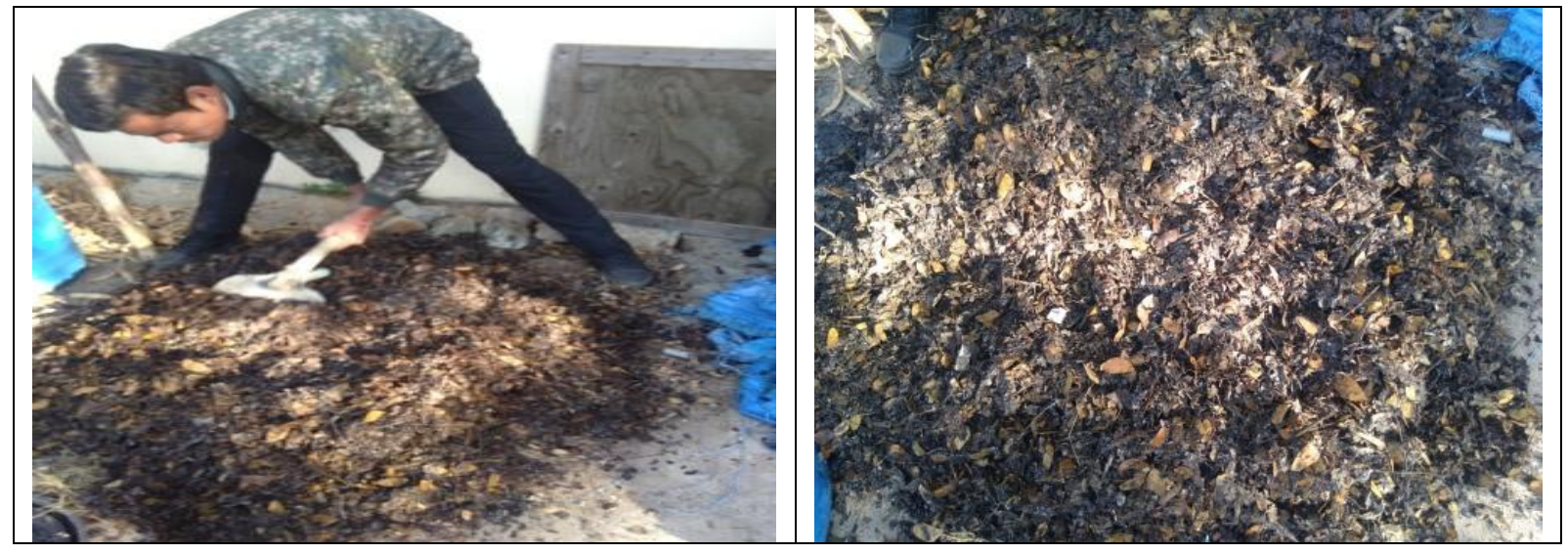

Fig.5 Growth of isolates on NA medium

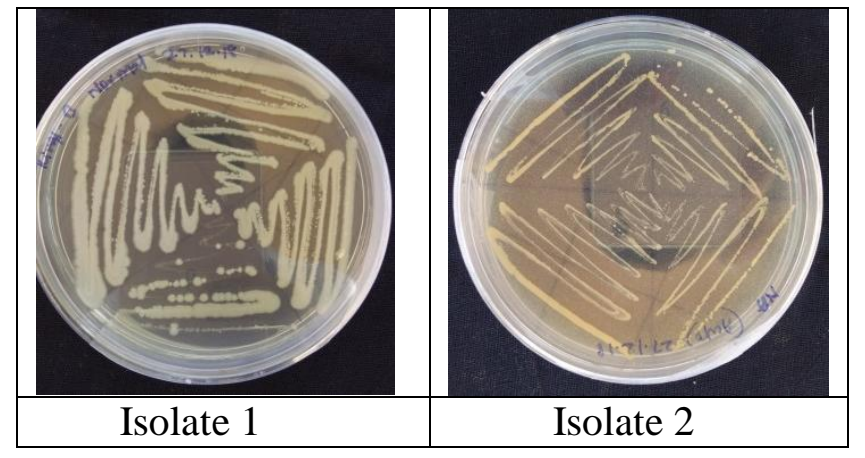


Fig.6 Growth of Spinacia oleracea performance in different compost

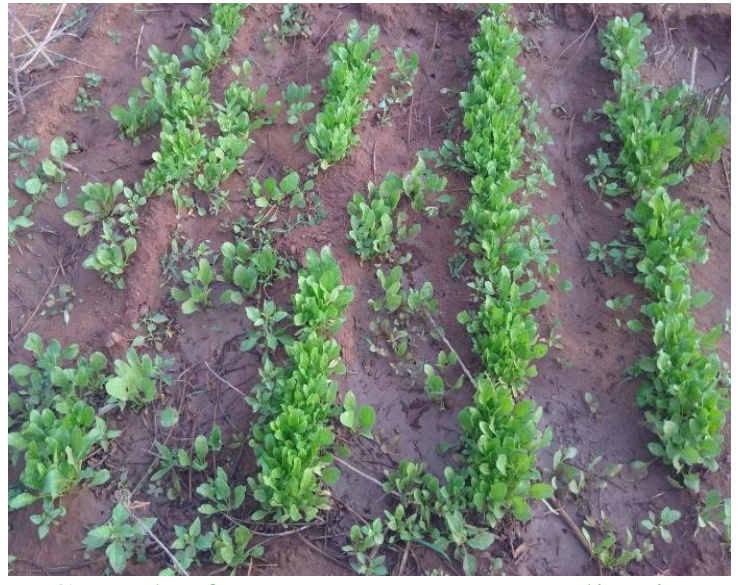

Growth after FYM compost application

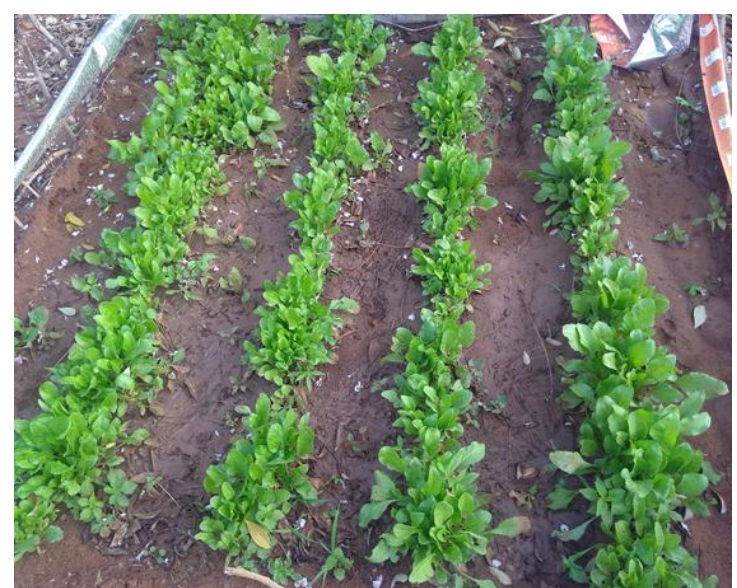

Growth after vegetable waste compost application

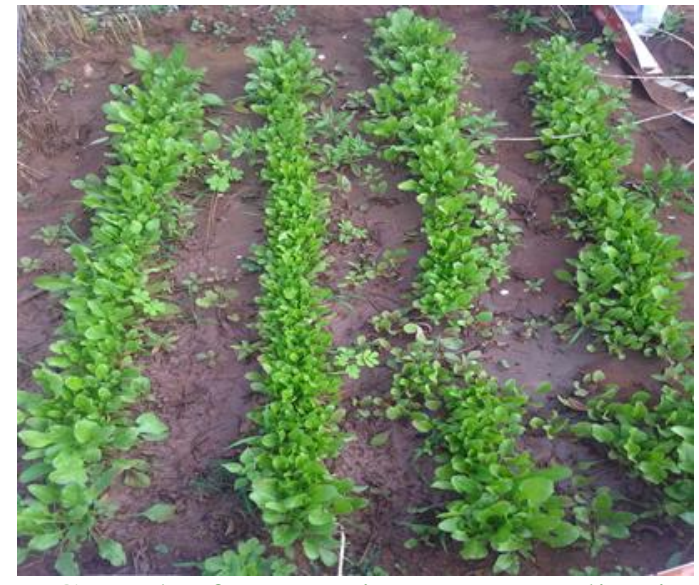

Growth after vermicompost application

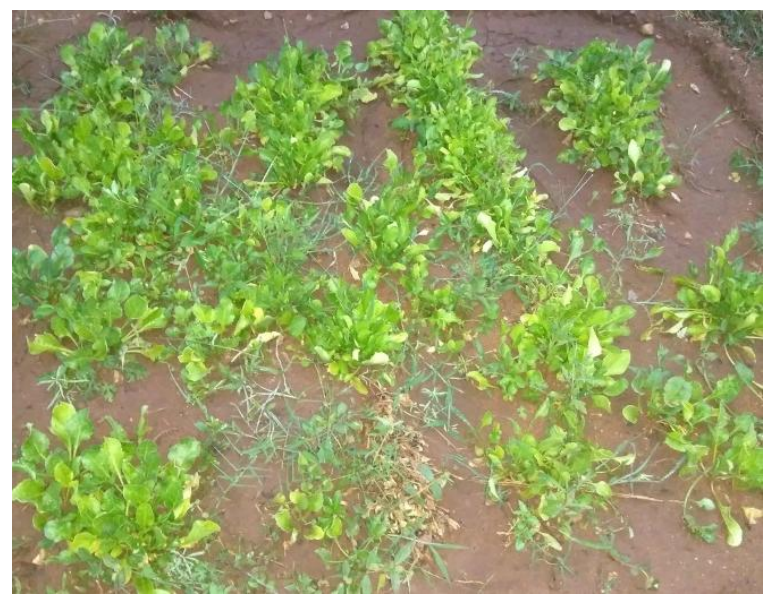

Growth without compost application

Fig.7 Growth of roots of Spinacia oleracea in different compost

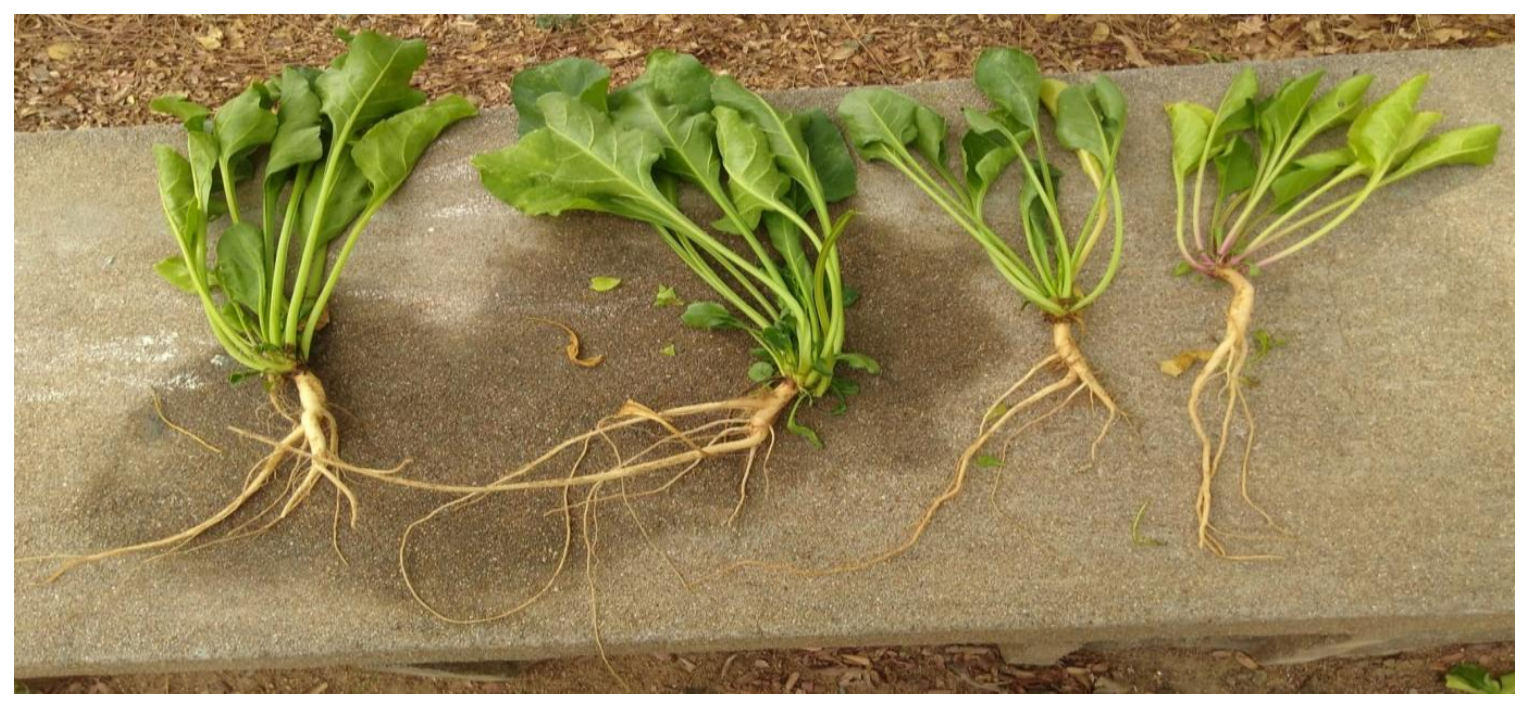




\section{Growth of Spinacia oleracea in different compost}

Growth was best in the plot where vegetable waste compost applied followed by vermicompost and FYM compared to control (without compost application). Root length and shoot length were found increased in all the compost planting compared to control. Following figures shows the differences of growth (Fig.6 and 7.)

The time taken for the degradation process to form compost was 50 days. In the case of vegetable wastes, the decomposition process was started after the application of the inoculum which was visualized clearly after 15 days of application by appearance of microbial growth. A sharp decrease in volume and colour change, development of pleasant odour, changes in texture and less water activity was seen. The same observation was seen rapidly in the successive days also. The complete decomposition was clearly observed on the 50th day, which was clearly identified by sharp decrease in volume (3/4th of the volume) complete decolourization, complete absence of water content and complete conversation of finely ground powder which reveal the decomposition of vegetable wastes into fine powder. The temperature of the compost was increasing gradually in the first week and attained maximum on 15th day and started decreasing after wards. After a month it reached to the normal. Composting activity was best at a moisture content of $40-60 \%$ by weight. At lower moisture level, microbial activity is very much limited. At higher levels, the process is likely to become anaerobic and foul-smelling.

In conclusion, NIPHM developed the method for composting vegetable waste and leaf litters and also NIPHM developed bioinoculum which accelerate the decomposition process. The Spinaciaoleracea was superior to other compost (FYM and Vermicompost). Further more research is required to study the effect of vegetable compost on each component of plant health.

\section{Acknowledgement}

We are thankful to the Director General, NIPHM for research guidance and support. We would also thank security guards and housekeeping staff of NIPHM for their help in collecting the vegetable wastes throughout the study.

\section{References}

Atiyeh RM, Edwards CA, Subler S, Metzger J (2000b) Earthworm-processed organic waste as components of horticultural potting media for growing marigold and vegetable seedlings. Compost Sci Util, $8(3): 215-253$

Albanell, E., Plaixats, J., Cabrero, T., 1988. Chemical change during vermicomposting (Eiseniafoetida) of sheep manure mixed with cotton industrial waste. Biol. Fert. Soils 6 (3), 266-269.

Bhiday MR. 1994. Earthworms in agriculture. Indian Farming 43(12): 31-34.

Gautam SP, Bundela PS, Pandey AK, Awasthi MK, Sarsaiya S. 2010. Composting of municipal solid waste of Jabalpur city. Global J Environ Res.; 4: 43-46.

ISI Bulletin. 1982. Manak Bhavan, Bahdur shah Zafar Marg, New Delhi. Jakson, M. L. Soil chemical analysis. Practice Hall, New Delhi, pp.498.

Thiruppathi, Senthilkumar; Sivakumar; Sudha; K. Alagusundaram. (2005). A Quick Method of determining the Moisture Content of Fruits and Vegetables. Conference paper "Post Production Systems and Strategies to the issues and Challenges of Food 
Safety and Security, Coimbatore September 22-23, 2005. 8p, At Coimbatore.

Viel, M., Sayag, D., Andre, L., 1987.Optimization of agricultural, industrial waste management through in vessel composting. In: de Bertoldi, M. (Ed.), Compost: Production, Quality and Use. Elsevier Appl. Sci., Essex, pp. 230-237.

Walkley, A. and I. A. Black. 1934. An examination of Degtjareff method for determining soil organic matter and a proposed modification of the chromic acid titration method. Soil Sci. 37: 2937.

\section{How to cite this article:}

Girish, A. G., P. Sakthivel and Alice R. P. Sujeetha. 2020. A New Method of Compost Preparation from Vegetable Waste and Dried Leaf Litters. Int.J.Curr.Microbiol.App.Sci. 9(08): 281-290. doi: https://doi.org/10.20546/ijcmas.2020.908.033 